\title{
NEGATIVE SOCIAL PHENOMENA, SOCIALLY PATHOLOGICAL PHENOMENA, PROBLEM BEHAVIOUR, RISK BEHAVIOUR WITH FOCUS ON SCHOOL ENVIRONMENT
}

\author{
Petra Hedrichová, Jitka Skopalová
}

\begin{abstract}
On one hand, the article is aimed at terminological and content interpretation of designations of socially unacceptable behaviours. When studying both Czech and foreign specialized literature, we noticed terminologically fragmented and unequal designations of behaviours (often the same or similar) with a common characteristic of being socially unacceptable or negatively evaluated and perceived by the society. Additionally to the risk behaviour, understood by us as a superordinate term, we found also the following designations of socially unacceptable behaviours: problem behaviour, deviant behaviour, delinquent behaviour, antisocial, disocial, asocial behaviour, socially pathological phenomena, etc. On the other hand, the article has the purpose to present selected theoretical concepts and constructs explaining the causes of risk behaviour. The theoretical concepts searching the causes of risk behaviour are mostly focused on one area of variables - biological, psychological or sociological. But we believe that the human personality and behaviour must be viewed from multiple sides, that multiple factors are simultaneously involved in the emergence and incidence of risk behaviour, and that one form of risk behaviour influences the origination of another risk behaviour.
\end{abstract}

\section{Keywords}

problem behaviour, risk behaviour, social deviation, social norms, social pathology

\section{Introduction}

Socially unacceptable behaviours are called in summary socially pathological phenomena, deviant, delinquent and criminal behaviour, antisocial behaviour, problem behaviour, and risk behaviour. Risk behaviour includes activities that can, directly or indirectly, damage 
the individual's successful development or lead to psycho-social and health problems of the actor or of other persons (Cvečková, 2010; Macek, 2003, Širůčková, 2009). Individual risk behaviour forms affect and condition each other, they are interconnected and interrelated. It was demonstrated that specific risk behaviour displays occur together, having similar causes and protective and risk factors (Jessor, 1995).

Risk behaviour constitutes the greatest danger particularly to children and adolescents who are the least resistant against different undesirable influences and who use inadequate solutions when solving their problems. They are easy to influence, unable to realize the consequences of their behaviour. Adolescents long to get their peers' appreciation, to become independent, they are highly critical, they experiment, test their limits and the adults' responses to them, they try to imitate the adults' behaviour. All that can, in our opinion, contribute to origination and development of risk behaviour.

Unfortunately, risk behaviours are present even in the school environment, i.e. at the place where children spend a substantial part of their day, thus becoming an undesirable part of the life of the school and affecting both the pupils and the teachers. The school, together with the family and with the peer group, plays an important role in shaping the child's personality, in influencing the upbringing and education, leisure time activities, work with the children's values and attitudes. It can work as a protective factor, but also as a risk one. For example a negative school climate can constitute a risk factor for the individual, similarly as for example the membership in a minority, urban environment or low social status of the family, etc. (Espozito, 1999). On the other hand, the school acts as an important protective factor, particularly in the area of risk behaviour prevention. Specialized literature (e.g. Fischer \& Škoda, 2014; Hrčka 2001; Kraus \& Hroncová, 2010; Miovský et al., 2010; Mühlpachr, 2008; Urban \& Dubský, 2012, etc.) qualities different concepts designating the behaviour forms and the phenomena considered undesirable by a given society or culture, contradicting social (religious, legal, custom and moral) norms or often prohibited. Socially unacceptable behaviours have for example the following designations: aggressive behaviour, antisocial behaviour, asocial behaviour, delinquency and delinquent behaviour, deviant behaviour, criminal behaviour, addiction behaviour, negative social phenomena, unadaptable behaviour, problem behaviour, risk behaviour, socially pathological phenomena, etc.

The above stated terms are often not only considered identical but also understood as synonyms for one fact. On the contrary, sometimes the given terms have different meanings, which is mostly related to different intensity of dangerousness attributed to the respective phenomena. Unequal terminology can lead to incorrect understanding of the given issue.

Risk, delinquent, deviant or other above stated behaviours are influenced not only historically and culturally, but also by the urbanization of the society, by the technicaltechnological development, by changes of traditional values or by social perception of norms and normality. Of course, during the development of the society, the approach of the society to behaviours considered "normal" and, on the contrary, to what is not in compliance with norms and norms develops and changes too. 


\section{Social Norms}

As Kudrjavceva et al. (1988) state, social norms constitute a model of human behaviour, determining goals, opportunities, forms, conditions of the behaviour. Unlike other norms (technical, medical, etc.), social norms regulate such behaviours that are related to mutual relations among individuals, groups and the society. Similar delimitation can be found also in the work of Jandourek (2012, p. 170), a Czech sociologist who states that "social norms define the forms of behaviour in a social situation". Ondrejkovič et al. (2000, p. 21) additionally defines social norms as "regulations for expected or even required social behaviour with the character of categorical imperative."

In general understanding, a norm represents a "verbalized rule to be respected by the individuals in their behaviour and considered as binding to them" (Maříková, Petrusek, \& Vodáková, 1996, p. 692). Geist (1992) works on a similar concept, stating that the norm can be seen in each rule, measure, regulation or model with binding validity, or a criterion serving to assess a specific phenomenon.

Social norms, or social rules, respectively, constitute an indispensable part not only of the life of the individual but of the whole society. They determine the individual's behaviours understood as desirable, covetable, acceptable and adequate, but they also set behaviours and behaviour patterns considered undesirable and unacceptable by other people or by the society, respectively. Adherence to norms is important to maintain the cohesion of the society and the social order. If people do not adhere to rules, there would be confusion and chaos in the society.

Vágnerová (2001) means that the knowledge of norms and rules is important for the individual as it satisfies the need of assurance and orientation. The individual knows how to behave in order to be positively evaluated, what behaviour is acceptable, what behaviours are and are not tolerated by the society. Additionally to the knowledge of the relevant norms, the interpretation of the given norms is important too. The interpretation may depend, to some degree, on the emotional relation to the given fact or on the individual's intellectual level. The knowledge and respect of the norms is an indispensable condition for the individual's adaptation process allowing the individual to live in a specific society, to be its member.

Each human acquires different rules to behave during life. They include conscious rules observed and followed by the individual as they are considered correct by and could be beneficial to the individual; they also include unconscious rules the individual acquires during childhood (Giddens, 1999).

But we can also see cases in which the standards or sets of standards are not exactly observed equally by all people. It can be stated that no norm is observed always under all circumstances and in all its range. "The observance of a specific norm is evenly distributed under normal circumstances" (Ondrejkovič, 2002, p. 133). That means that extreme behaviours, both positive and negative, occur less than conforming behaviours in the society.

The thing is that there is a tolerance limit, an area where it is socially acceptably to violate the norm to some degree (Petrusek, 2009). Thus the tolerance limit determines 
what degree of deviations from the norm are tolerated within the society. There is for example different tolerance towards consumption of alcoholic drinks, from absolute ban, prohibition or delimitation of places and times where alcohol may be consumed, to toleration of some amount of alcohol consumed for example at New Year's Eve. The range of the tolerance limit depends on the specific situation, culture, and traditions.

\section{Social Control and its Mechanisms}

In order to work well, each society must have mechanisms to defend itself against the individuals violating the norms and to exert pressure on the individuals to adapt to written and unwritten norms, i.e. to behave conformably. Thereby, it tries to minimize the incidence of social conflicts and, on the other hand, to increase the chance to satisfy the needs of all its members. As G. Munková (2004) states, people observe standards thanks to the existence of social control mechanisms aimed not only at producing fear of violating norms and rules but also at preventing social conflicts or, in case of people who have violated the norm already, at eliminating their urge to do it again and at teaching them to behave "normally" (Urban \& Dubský, 2012).

To enable the individual to learn socially healthy behaviours, to acquire socially conforming behaviour during the socialization process, formal and informal social control mechanisms must work sufficiently and flawlessly, as they can play a crucial role in preventing or minimizing the origination and incidence of deviations. Hrčka (2001) ascribes an important role to informal control executed by the family, friends, coworkers, neighbours, etc. It includes for example parent supervision, relations of adolescents to their parents, teachers, adaptation at school, relations to classmates, etc., which are closely correlated with risk behaviour. If the informal control of observance of certain norms is insufficient and unsatisfactory, or completely missing, formal control acquires importance. It usually has an institutionalized form and is executed by state organizations, authorized to apply force and pressure (different authorities, the police), and by nonstate organizations (e.g. the Church, a club, a company, etc.) (Urbanová, 2006).

It is difficult to determine an exact boundary between formal and informal control. In smaller groups and communities, informal control can have more effect; people in such groups are more controlled by other members and there are less opportunities to violate the norms. On the other hand, the present is characterized by substantial development of city life with increasing anonymity and mobility of population that may lead to weaken the influence of informal control.

The above stated social control types constitute external social control consisting in imposing different sanctions, both in form of rewards for conforming behaviour or in form of punishments for violation of norms or in form of loss of the existing reward, respectively.Additionally to external control, there is also internal control leading the individuals to regulate their behaviours and attitudes based on specific norms and rules the individuals have acquired during socialization and identified with them, which allows 
the individuals to distinguish the correct from the incorrect behaviours. Violation of such norms may provoke guilt, remorse, guilty conscience, which can be considered a kind of sanctions with potential negative impact on the individual's psyche.

Urbanová (2003) sees regulation mechanisms in human life in the fear of negative consequences of violation of rules on one hand and, on the other hand, in the individual's conclusion that observance of rules is more advantageous than their violation. A degree of belonging to a given group may also play its role, as a potential violation of norms could result in loss of the individual's position in the group. Mühlpachr (2001) adds that respecting of norms can be based on the individual's own conviction, if the individual is convinced about the rightness of the given norm. But more frequently, the actual reason for the people to observe norms and rules consists in their fear of sanctions that would follow their violation. For example in school environment, the pupil faces two forms of norms. On one hand, there are formally, institutionally given school rules. The pupils may not internally accept the rules, they even may not identify with them. But they know that they must respect and observe them. The observance of the school rules must be controlled (mostly by teachers), and if the norms are violated, the behaviour is usually punished. But the pupils also face unwritten norms of their class, the peer group norms. The pupils' attitude to institutional and unwritten norms substantially differs. The rules of the class are accepted as norms of an informal group. Most pupils accept them, identify with them, consider them proper, and therefore behave in compliance with them. An individual who does not adapt to the class norms, resists social pressure, is somehow different, is often excluded from the group, isolated, and may even become victim of bullying (Vágnerová, 2001).

It is not easy to distinguish what is still normal and what is already a deviation - departure from a social norm, as the determination of deviation is conditioned by the definition of normality ${ }^{1}$, explained by Jandourek (2007, p. 172) as the "condition of the individual, group or society corresponding to established norms and accepted values." There is not an exactly set boundary between normal and deviant behaviour. The boundary of the norm is unstable, it depends on the specific social, cultural and historical context.

The determination of the norm may also reflect the current level of knowledge in a specific society. According to Vágnerová (2004), some behaviours may be perceived as abnormal, as people do not understand them, are not sufficiently informed of them, or on the contrary, the behaviours are conspicuous, draw more attention, and thus may be considered abnormal. The assessment of abnormality is also influenced not only by the development level achieved by the assessing person (different opinions of children and adults about the same offences), but it also depends on the system of social values and the resulting attitudes or on the specific social context (Fischer, 2006).

\footnotetext{
${ }^{1}$ The issue of normality in the area of psychology and psychiatry was discussed in detail by E. Syřištová in her book "Normality of personality". E. Syřištová et al. (1972, p. 14) states that "the problem of normality of personality (of the behaviour) has its roots in general biological relations on one hand and in specific relations of mental development and psychosocial interactions on the other hand".
} 
The assessment of normality also considers development factors; for example the behaviours of younger children is assessed with higher level of tolerance, so that they can achieve the required norm. This approach respects the fact that the development of individual children can have different progress. The period of childhood, or adolescence, respectively, is considered by Czech and foreign experts (e.g. Erikson, 2002; Langmeir, in Syřištová et al., 1972; Piaget \& Inhelderová, 2010; Říčan, 2004; Vágnerová, 1997) the most dynamic period of human life, during which extensive changes occur in all personality components. It is therefore sometimes difficult to determine whether a child's further development will progress normally or whether it will deviate from norm; that's why it is important to aim at the right selection of upbringing, therapeutic and other actions and at a timely intervention, as a later and inadequate intervention may not be effective (Langmeier in Syřištová, 1972). Sometimes, the individual may also be inadequately evaluated due to deviations from "population averages", which may lead to inaccurate, bad diagnostics and to subsequent inadequate actions, like placing the child into specialized school facilities, although there may not have been any real reason for it.

The previous text shows that normality can be assessed by different criteria and that the concept of normality can be handled by different theoretical approaches (e.g. Fischer \& Škoda, 2014; Urban \& Dubský, 2012; Vágnerová, 2004, etc.):

- Statistical approach to normality - normal is what occurs most frequently or what shows features of the average. Statistical normality correspond to what is common and most widespread in the society. In simple words, normal is what the majority does. A disadvantage of this approach can be seen in the fact that normal behaviour is seen in average behaviour, while on the contrary each deviation from the average, overstepping the boundaries of deviations, is considered abnormality (deviation). One of the disadvantages consists in the abnormality of the phenomena that can be beneficial to the society. The examples include individuals with exceptional talents and natural abilities or genial persons who do not appear in the average zone, and therefore may be considered strange, abnormal personalities by their surroundings.

- Normative approach to normality - expresses compliance with social norms and individual and group norms. But this approach implies some risks too. Behaviours that are perceived as normal and trouble-free, corresponding to national regulations by members of one nation can be perceived as deviant by members of other groups, and vice versa.

- Functional approach to normality - this approach considers normal what contributes to optimal function of the individual or the group in the society. Thus we can state that the essence of functional approach of normality consists in a specific system fulfilling correctly its function. A problem can consist in objective delimitation of optimal functioning. Optimal functioning can be seen in achieving of a specific goal or in satisfaction of individual needs of the individual.

- Ideal approach to normality - this approach specifies a model, a perfect status, process that should be achieved. Thus everybody who does not achieve the perfect 
level is abnormal. The effort to achieve the ideal fulfils the motivation function on one hand, but on the other hand, it also implies risks, as the achievement of the ideal, of perfection is an unrealistic and unachievable goal, which can lead to frustrations, disorders and problems (e.g. the effort to approximate the ideal of female beauty often leads to serious easting disorders.

The above stated facts show that there are multiple ways to delimit normality; they are situationally, culturally and historically variable but do not exclude each other. It cannot be determined which approach is correct or the best, as each of them has its positive features, but also limitations, and they are often mutually combined.

\section{Negative Social Phenomena, Socially Pathological Phenomena, Problem Behaviour, Risk Behaviour}

In our opinion, the concept of negative social phenomena designates a broader scale of socially undesirable phenomena, from less serious offences to serious crimes. We support the opinion of Skopalová (2000 p. 3) who understands as negative phenomena "all undesirable behaviours, i.e. behaviours deviating from the given norms, primarily from moral norms. Thus the issue is broadly delimited, from relatively small offences and misdemeanours like lie or impudent, defiant behaviour to asocial behaviour like bullying to really socially pathological phenomena, e.g. criminality, all addictions, involuntary prostitution, etc."

On the contrary, Hrčka (2001) sees the use of the concepts of negative social phenomena or even antisocial phenomena and behaviours as unacceptable, as they imply negativity and ideological subtext in their essence. That opinion is supported by Mühlpachr (2008) who thinks that such designation does not guarantee a value and emotional neutrality (some negative social phenomena may not constitute a violation of generally recognized norms and rules).

Socially unacceptable behaviours are often designated with the term socially pathological phenomena (social pathology). ${ }^{2}$ There is no unified definition or delimitation of social pathology3. For example Pokorný, Telclová \& Tomko (2003) understood socially

\footnotetext{
2 The concept of social pathology (from the Latin pathos - suffering, disease) designates a scientific discipline, a study branch, as well as a summary designation of undesirable phenomena in the society. The concept of social pathology was introduced into sociology by $\mathrm{H}$. Spencer who, in the $2^{\text {nd }}$ half of the $19^{\text {th }}$ century, dealt with the idea that there is some parallel between biological pathology (disease) and social pathology, i.e. a disease of the society, between the biological and social organism (Kapr, 1997).

${ }^{3}$ E. Durkheim considered social pathology a "science dealing with morbid and adverse facts, behaviours that deviate from the set norms, but at the same time constitute an organic component of life of social groups". (Kapr, 1997, p. 94). Podgórecki (1969, p. 24) defined social pathology as "such behaviour, such type of organization, such type of social system function that is in basic contradiction with the values accepted and recognized by the given society." According to Hartl \& Hartlová (2010), social pathology is an obsolete term for sociology disciplines dealing with the progress and conditions of abnormal social processes like criminality, alcoholism, job related accidents, traffic accidents, socially conditioned mental disorders, job related injuries and illnesses, poverty and unemployment, etc.
} 
pathological phenomena as behaviours characterized by nonobservance and violation of social norms and laws on one hand, and on the other hand by unhealthy life style that leads to health problems of the individual and to damage to the environment, causing individual or society-wide disorders.

As Ondrejkovič et al. (2000, p. 9) state, socially pathological phenomena constitute "unhealthy, abnormal, generally undesirable social phenomena" to which higher degree of social seriousness and danger is attributed and which violate legal norms. They include negatively sanctioned forms of deviant behaviours (Krejčířová \& Skopalová, 2007). Many socially pathological phenomena rather have individual character and impact, e.g. alcoholism or suicidality. Nevertheless, they may have society-wide consequences.

Bláha (1968) understands socially pathological phenomena as consequence of inadequate arrangement of social conditions and of disorders in social processes and social systems. The assessment of a specific phenomenon to see whether it does or does not rank among socially pathological phenomena depends on the specific time and place and is based on the approach to normality, accepted by the given society. A given phenomenon is not equally understood always and everywhere. That depends both on the differences of individual cultures and on the differences of their social norms and on the time in which they are assessed. The same phenomenon may be evaluated from common to unacceptable behaviour in different cultures. For example the consumption of alcohol is tolerated to a considerable degree in our country, while it constitutes a gross violation of norm in the Islamic world. What is termed as a socially pathological phenomenon, may not have been termed as such some years ago (mobbing, bossing), or even did not exist (cyberbullying). On the contrary, phenomena formerly considered socially pathological in our country are now stipulated by legislation (civil union). Thus we can state that socially pathological phenomena are socioculturally and historically variable.

Kvaśniewski (1991) thinks that additionally to historical and sociocultural determinants, the different evaluation of social phenomena as desirable or undesirable is influenced by subjective opinions of the individual who perceives specific social phenomena as negative.Although there were efforts to overcome the subjective assessment of socially pathological phenomena, an unambiguous definition or list of pathological phenomena could not be successfully created.

On the turn of the $20^{\text {th }}$ Century, socially pathological phenomena included primarily criminality, suicidality, alcoholism, homosexuality and other sexual deviations, prostitution, divorceability, or also unemployment and war. Later, drug abuses, drug addictions, violence, aggression and hooliganism were added (Kapr, 1994; Ondrejkovič, 2000). Hroncová, Kraus (2010) include also e.g. unemployment, poverty and accident tendency among socially pathological phenomena. Socially pathological phenomena can include also veneral diseases, runaways, parasitism, low social adaptation, divorces, violence in family, deprivation of parent rights, bureaucracy, corruption, and organized crime (Stankowski, 2001).

In 2010, Marešová (p. 53) listed the following phenomena understood as pathological: 
- alcoholism, drug addiction and other addictions including pathological gambling,

- membership in extremistic groups and religious sects, racism, xenophobic behaviours, violent behaviours at demonstrations,

- domestic violence, stalking,

- bullying at school, at the workplace, social harassment,

- prostitution, promiscuity, involvement in porn production, pimping, commercial sexual abuse,

- gambling, including gambling without the character of pathological addiction,

- vandalism, graffiti vandalism, violence at sport stadiums, street violence,

- antisocial behaviour spread through the Internet and social networks,

- suicides,

- corruption, clientelism,

- creation of street gangs among minors, homelessness.

The concept of social pathology was broadly used until the 1940s; later, it was replaced by the concept of social deviation, both due to excessive analogy with the biological organism, widespread in the society, and due to the fact that the concept of social pathology may evoke negatively toned connotation of a social phenomenon.

In our opinion, the use of the concept of social deviation is more apt, as it does not determine the specific norm from which the behaviour deviates, as it does not state whether the deviation is positive or negative, and it also does not state whether the deviant behaviour is bad or good ${ }^{4}$ (Maříková, Petrusek, Vodáková, 1996).

Fischer and Škoda (2014), Bártlová (1998) tend to believe that the concept of social pathology cannot be identified with the concept of social deviation, as deviant phenomena may not always be pathological. Socially pathological phenomena can include phenomena which are negative, harmful or endanger the individual or the society. That is why both concepts should be distinguished and the general context should be considered when using them.

Social deviation is understood by Ondrejkovič (2002, p. 127) as a "sub-class of social behaviour and at the same time as a term for designation of a deviation from the expected standardized and institutionalized behaviour prescribed by the social norm applicable in a specific society, group, social structure." Jedlička et al. (2004) see social deviation in every behaviour that does not meet or exceeds social expectations and provokes social disapproval.

According to Ondrejkovič (2002), social deviations can be viewed from different perspectives, for example as:

\footnotetext{
${ }^{4}$ But on the other hand, it should be noted that even the concept of deviation can be preconceived as negative. Hrčka (2001) points out that the term of deviation is usually not used to designate positive qualities and situation but, in most cases, is related with negative evaluations, ideas, denominations of phenomena and characteristics.
} 
- legal definitions - based on violation of norms codified by law,

- norm-oriented definitions - based on violation of social norms,

- definitions focused on the expected behaviour in specific situations,

- sanction-oriented definitions,

- definitions including quantitative factors,

- constructivist definitions - focused on moral and cognition,

- definitions dealing with social control sanctions,

- definitions based on violation of ethnic, custom and other norms.

Deviation is generally defined as every deviation from a norm. Thus it includes not only the violation of a norm but also the exaggeration of a norm and taking it to extremes. In this context, we speak of positive deviations (abstinence) and negative deviations (alcoholism). They may occur at any phenomenon in the nature or in the society. Deviations have universal character; we can find them in all societies, from geographical, cultural and historical perspective. "There is no society or culture that has a completely conforming behaviour of its members with absolute absence of deviations." (Mühlpachr, 2008a, p. 44)

Experts (e.g. Kudrjavcev et al., 1988; Hrčka, 2001; Urban, Dubský, 2012; Sochůrek, 2009) further distinguish social deviations into:

- primary deviations (violation of a norm based on an original impulse) X secondary deviations (originate from the individual's designation as a delinquent);

- social deviations (have importance in social relations and interactions) X non-social deviations (there are no social relations and interactions among the subjects and they do not establish an organized community);

- deliberate premeditated deviant behaviour X careless, impulsive deviant behaviour.

In connection with social deviation, the concept of objective deviation should be mentioned; it emphasizes the important role of norm violation on one hand and on the other hand requires meeting of further conditions, particularly (Kapr, 1997):

- repeatability - violation of a norm in time and in different territories,

- mass scale - the norm violation must occur in larger population groups,

- social seriousness attributed to a specific behaviour in the given culture or society,

- similarity or identity of causes.

As Urban \& Dubský (2012) state, each deviation has its internal structure. It consists of:

- subject (individual, group) behaving in a deviant manner;

- object (thing, individual, group, social values) focused by the deviant behaviour;

- content - individual deviant behaviour patterns;

- goals - lead to satisfaction of needs;

- consequence of deviant behaviour - guilt, normalization of deviant behaviour, etc. 
It is not convenient to explain deviant behaviour only through the individual who behaves in a deviant manner. There are some other factors and facts involved in the deviant behaviour of an individual, e.g. applicable social norms, sanctions used by the society in case of violation of the norms, value system, etc. Thus social deviations usually do not have only one cause, but a number of causes that influence each other and combine with each other.

Problem behaviour ${ }^{5}$ is usually understood as a "behaviour that is socially defined as a problem, as a source of concerns or as unacceptable with respect to norms of the general society" (Jessor \& Jessor, 1997, p. 33, in Širůček, Širůčková \& Macek, 2007). As Langr (2001) states, we can speak of problem behaviour in school environment when a pupil shows distinctive drawbacks in school results and in behaviour, disrupting the educational process. Vágnerová (1997) distinguishes three areas of pupil drawbacks and problems that may lead to attribution of the role of a problem pupil: problems in the area of school results, problems in the area of behaviour and problems in the area of emotional experiencing.

We are focused on problems in the area of behaviour. A pupil with discipline problems makes the teaching conditions difficult to the teacher and reduces the teacher's action upon other pupils by problem (unsuitable) behaviour. The pupil does not meet the teacher's expectations and repeatedly deviates from the norm by his/her reactions, attitudes, opinions and performances. The teacher may perceive such a pupil as a burden, as he/she requires special approach and attention (Vojtová, 2004).

If a pupil is designated as a problem pupil, it may have the effect of a social stigma that has a negative impact on the pupil's self-image, self-conception and self-assessment, it provokes a negative emotional experience and may distinctively influence not only the pupil's further attitude to school, to the teacher, to school duties and to the classmates (Kohoutek, 2000) but also the pupil's acceptance (or non-acceptance) by other teachers (Vojtová, 2004a). The label of "problem pupil", "pupil with behaviour disorder" may become a barrier on the way to promising socialization. Vágnerová (2001) highlights the danger of acceptance of the opinion or assessment of one teacher unreservedly by other teachers, as it may lead to labelling and to a negative attitude of the teachers to the given pupil.

We have seen the above stated situation several times during our teaching practice, as some teachers consider it easier to accept the opinion, attitude, conclusion expressed by somebody else, particularly if it was expressed by a more experienced colleague, than to think of potential solutions of the given situation.

Problem behaviour includes different types and forms of behaviour with different degrees of seriousness. They include not only behaviours like forgetting of aids, cribbing,

\footnotetext{
${ }^{5}$ According to Jandourek (2012), the behaviour is the response of the organism to changes in its surroundings, displayed by activities, mimics, speech. The behaviour constitutes the sum of external displays, activities, actions responses of the organism (Hartl \& Hartlová, 2000). Sometimes, the concept of behaviour is incorrectly interchanged and identified with the concept of actions. Actions are defined as deliberate behaviour based on a specific motivation and changing the existing state or situation (Hartl \& Hartlová, 2000).
} 
disturbing and provoking the teacher (Vágnerová, 2001) but also more serious behaviours like lying, cheating, thefts, bullying, truancy, smoking, consumption of alcohol, runaways from home, etc. (Čáp, Mareš, 2007).

Vojtová (2004) distinguishes, from the perspective of ethical pedagogy, two categories of discipline-problematic children 6 : children with behaviour problems and children with behaviour disorders ${ }^{7}$. She sees the differences between the two categories in three dimensions:

1. in the individual's motivation to the behaviour,

2. in the time dimension of the undesirable behaviours,

3. in the intervention and re-education methods.

A pupil with behaviour problems, unlike a pupil with diagnosed behaviour disorders, knows about his/her problems and does not violate the norms intentionally. Such pupil would like to change his/her behaviour. Problems in the pupil's behaviour occur randomly, often in specific periods. They are caused by uncontrollable and unsolved conflict situations with classmates, parents, etc. The school should strive to correct the problem behaviours through adequate purposeful procedures and methods (Vojtová, 2004a).

To manage the problem behaviour within the school, the teacher should try to find out the cause, the source of the behaviour. But that may not always be successful. Although the probable cause of the undesirable behaviour is obvious, the school or the teacher may not always be able to eliminate the cause of the problems and to solve the situation (e.g. problematic family environment).

Many external and internal factors are involved in the origination of problem behaviour of children and young people, and the factors complement each other and are mutually combined. Additionally to biological variables, the behaviour is also influenced by variables resulting from social environment, like attitudes, opinions, models in the family, at school, in peer group, locality, the media, as well as subjective perception and assessment of social environment and individual qualities (Čáp, Mareš, 2007).

\footnotetext{
${ }^{6}$ But the two names are sometimes identified or interchanged. A pupil with problem behaviour can be designated as a pupil with a behaviour disorder and the pretext that such pupil "does not belong to school" may lead to tendencies to place the "problem" pupil to specialized school facilities. According to Žlunková (2010) and Vojtová (2004), a pupil with a behaviour disorder should be distinguished from a pupil with problem behaviour, and in case of the pupil with problem behaviour, the school should strive to induce a change and correction of the undesirable behaviour through adequate purposeful pedagogical actions. We can state, based on our personal teaching experiences, that such change of behaviour of problem pupils is possible primarily if it is supported by the family and if the mutual cooperation of the school and the family works well.

7 Vágnerová (2004, p. 44 ) characterizes behaviour disorders as "a deviation in the socialization area, when the individual is not able to respect behaviour norms at a level corresponding to his/her age or at the level of his/her intellectual capacity, respectively." In general, behaviour disorders of children and young persons can be seen in the individual's repeated and long lasting (at least 6 months) not respecting social norms, not feeling guilty, not being able to establish and maintain acceptable social relations. According to the author, the displays that can indicate a behaviour disorder include: lying, truancy, rambling, runaways, thefts, aggressive behaviour, bullying.
} 
Some problem behaviours like disturbing, shouting out, disobedience, provoking of teachers, aggressive behaviour, but also for example conspicuous clothing, hairstyle, loud laughter and speaking, "fooling around" are often aimed at capturing the attention of the teacher, the parents or the classmates. Čáp and Mareš (2007) speak of the attentioncapturing technique that often occurs in individuals who used to take the centre stage and later lost their privileged position.

The origin of delinquent behaviour is influenced by a number of factors, including internal factors and external circumstances. Matoušek, Kroftová (2003); Vágnerová (2004); Fischer (2006) see for example the following causes of delinquent behaviour: congenital dispositions, CNS disorders, hyperactivity syndrome, personality features, intelligence, influence of family, school, peer groups and gangs, influence of media, social and political context, ethnic origin, age, gender, degree of mental skills, achieved education level, position in the society, missing working habits, etc. Delinquent behaviour may also result from serious mental disorders and behaviour disorders (Vojtová, 2004).

Additionally to the above stated factors that may contribute to delinquent behaviour, a child may commit such behaviour because of seeking "substitutive satisfaction" due to loss or emotional deprivation. In such way, the child tries to achieve recognition and attention of his/her environment. Substitutive satisfaction is often displayed by so called substitutive thefts, runaways and rambling while the children are not able to substantiate their actions (Balaštík, 1996). Delinquent behaviour may also stand for "call for help" (for example if one of the parents dies), when a child or a young person lands in a difficult life situations and displays anxiety and depression. Such child acts like in panic, does not know the motive of his/her behaviour and is not able to explain why he/she behaves in such manner (Říčan, Krejčírová, 2006).

Not only specialized literature (e.g. Dolejš, 2010; Hamanová \& Hellerová 2000; Miovský et al., 2010; Širůčková, 2009, etc.), but also governmental documents, strategies and concepts feature the term "risk behaviour" 8 . We can find many definitions of risk behaviour in literature. In the most general terms, risk behaviour can be described as a "behaviour that has negative impacts on the physical or mental functions of the individual and that is somehow endangering to the individual's environment" (Miovský et al. 2015, p. 161). The phenomenon of risk behaviour is studied by different science disciplines; therefore risk behaviour can be considered multidisciplinary. The medical perspective delimits risk behaviour as one of the factors affecting the individual's health and disease. Thus risk behaviour is understood as a risk factor leading to disease or even death. Another concept is offered by sociological sciences paying attention to the effects of risk behaviour on the individual's social relations, emotionality and performance in cognitive area (Širůčková, 2012).

\footnotetext{
${ }^{8}$ Specialized literature (e.g. Kaufmann, 2001; Labáth et al. 2001; Matoušek, 1996) also uses the term "risk youth" in connection with risk behaviour. Labáth et al. (2001) defines risk youth as youth in which increased probability of failure in social and mental area may occur through the effect of multiple factors. Matoušek (1996) speaks of risk youth as of young people stumbling on the threshold of adulthood.
} 
Miovský et al. (2010) understand risk behaviour as a behaviour leading to demonstrable increase of health, social, educational and other risks for the individual or for the society. It is a complex of phenomena whose existence and consequences can be scientifically investigated and influenced by adequate preventive and therapeutic procedures. Risk behaviour is similarly defined for example by Macek (2003); Širưčková (2009); Cvečková (2010). According to them, risk behaviour constitutes of activities that may have direct or indirect negative impact on the adolescent's successful development on one hand, and on the other hand may lead to psychosocial or health problems of the individual and of other persons, like injury, death, permanent handicap, etc., to disruption of relations, to damage of the environment or to economic and material losses.

Thus we can say that risk behaviour represents specific problems, dangers and negative consequences to the individual, that are nevertheless balanced out by subjectively perceived profits offered to the individual by such behaviour (Gullone \& Moore, 2000). Risk behaviour related to the period of adolescence includes behaviours with a broad range of forms, from less serious behaviours (cheating in writing exams, disturbing during school lessons) to behaviours characterized by high level of risk and seriousness (thefts, vandalism, etc.). So we understand risk behaviour as behaviour patterns leading to demonstrable increase of health, social, educational and other risks for the individual and for the society. This term replaces the former term "socially pathological phenomena". The term "socially pathological phenomena" is stigmatizing, normative, and puts too much stress on the group/social norm. It is used in sociology to describe phenomena in the society, not to describe specific behaviours of individuals or groups. It is a "complex of phenomena whose existence and consequences can be scientifically investigated and influenced by preventive and therapeutic interventions. Most frequently, we include the following behaviours in the concept of risk behaviour: bullying and violence at school, including other forms of extremely aggressive actions, further truancy, abuse of habitforming substances, non-substance addictions (gambling, problems related to failure to master the use of PC, etc.), abuse of anabolics and steroids, generally criminal behaviour, sexual risk behaviour, vandalism, xenophobia, racism, intolerance and anti-Semitism, commercial abuse of children, cruelty to children, child abuse, etc." (Miovský et al. 2015, pp. 28-29).

\section{Areas of Risk Behaviour}

Risk behaviour constitutes a broad range of negative behaviours in the adolescents' life. The specialized literature dealing with the issue of risk behaviours hardly offers a complete classification of risk behaviour forms; we have rather noted a concept and content disunity, fragmentation and risk behaviour surveys with different levels of dissimilarity.

Our goal is not to present a complete and comprehensive survey of individual risk behaviour classifications, but we would like to point out several basic delimitations of risk 
behaviour contents, which will allow us to view the issue of risk behaviour in children and youth from different perspectives.

In order to allow the incorporation of new forms and displays of risk behaviour into this system, some authors choose more general, simplifying classifications of risk behaviour. Labáth et al. (2001) divides the behaviours into three groups:

- aggressive forms - violence, criminality, extremism;

- passive forms - truancy, abuse of legal and illegal drugs;

- compromise forms - family and relationship problems, work fluctuations and other activities implying social and professional instability.

Macek (1999) supports a more general classification of risk behaviour too, dividing it into two groups. On one hand, there can be behaviours damaging the health of the adolescent; on the other hand, there can be risk actions of adolescents connected with danger to the society, i.e. with negative impact on or damage to other people.

An interesting classification is offered by Kloep, Güney, Cok and Simsek (2006, in Širůčková, 2009) who divide the risk behaviour based on motivation into:

- Irresponsible risking 9 behaviour - the primary goal of such behaviour does not consist in the experience of the risk in itself, but the risking behaviour serves as a means to achieve an end. The individual is not aware of potential consequences of his/her behaviour in the given situation, or is not ready to give up a present experience, although the risks implied in the given behaviour are obvious.

- Public-controlled risking behaviour - the adolescent may be motivated to the risk behaviour by the fear of loss of appreciation from peer group members or, on the contrary, by the effort to be accepted by the peer group or to strengthen his/her position. The peer pressure may be one of the causes of risk behaviour of adolescents, which is evidenced e.g. by the results of the study made by Jelínek, Květoň, Vobořil, Blatný, and Hrdlička in 2006.

- Excitement-seeking behaviour - the individual intentionally seeks excitement and wants to test his/her capacities and limits. He/she often resorts to such behaviour to chase away boredom or to have a strong adrenalin experience (risk sports). But risk sports imply some risks like: insufficient material equipment, insufficient information of the conditions of the environment and, last but not least, limited ability of recognizing own physical strength and physical resistance and overestimation of own capabilities.

According to Novotný \& Okrajko (2012), risk behaviour can take place in three basic areas:

\footnotetext{
${ }^{9}$ Risking behaviour can be characterized as a behaviour in which the person is fully aware of the risks connected with the behaviour. The awareness of risks may even be the drive, the motivation to the behaviour (Širüčková, 2009).
} 
1. risk behaviour in psychological area - behaviour disorders, delinquency, bullying, selfharm, suicidality, truancy, vandalism, xenophobia, racism, anti-Semitism;

2. risk behaviour in the area of reproduction health - early start of sexual life, promiscuity, risk sex;

3. risk behaviour in the area of abuse of habit-forming substances, or addictive behaviour, respectively - use of legal substances, abuse of illegal and virtual drugs, gambling.

We can also find risk behaviours related to the school environment. In this context, Širǔčková (2012) speaks of risk behaviour towards school institutions. Typical behaviours include failure to fulfil school obligations, learning failure, truancy, premature termination of school attendance.

We believe that, additionally to the above stated behaviours, this category can include also other behaviours accompanying the educational process and disturbing it considerably, like: pupils' indiscipline, disturbing, cheating at written exams, violation of school rules, vulgar speech, etc. But the school environment is also place of behaviours concerning not only the teaching process as such but related to the factors of the educational process, to school property and healthy life style (e.g. bullying, cyberbullying, racist behaviour, threats, aggression, thefts, damaging of school property, intentional avoiding of active involvement in physical education, smoking, consumption of alcohol, offering of legal and illegal drugs, etc.). Individual forms of risk behaviour are often interconnected, mutually conditioned and interrelated. Some risk behaviours occur together, they have similar causes. R. Jessor and S.L. Jessor (1977), relying on long years of research of risk behaviour of American youth, come to the finding that a person who behaves riskily in one way tends to behave riskily also in other areas of life. Most frequently, the following behaviours are interrelated: smoking of cigarettes, consumption of alcohol, use of marijuana, abuse of illegal substances, vandalism, delinquent behaviour, risky sexual behaviour. The interconnection of individual risk behaviours constitutes a form of a specific life style characterized by nonconformity. In this connection, R. Jessor and S.L. Jessor (1977) speak of the syndrome of risk (problem) ${ }^{10}$ behaviour.

We rely primarily on the Methodical advice for primary prevention of risk behaviour of children and youth at schools and in school institutions, Ref.: 21291/2010-28 (MŠMT, 2010) that came into force on November 1, 2010 and that suggests replacing the term of social pathological phenomena by the term of risk behaviour. The change was performed based on the use of the unified terminology within the EU countries. "The concept of socially pathological phenomena is a sociological concept covering fatal phenomena in the society (alcoholism, thefts, murders, etc.) at which the primary prevention actions should be aimed. Nevertheless, teachers in the school environment work with risk behaviour against which they take efficient primary-prevention measures in order to minimize the displays and risks of such behaviour, they possibly diagnose it and subsequently take efficient measures."

\footnotetext{
10 Both variants can be used. R. Jessor et al. (1977) use both the term "problem behaviour" and the term "risk behaviour".
} 
Although the term risk behaviour is closely related to other concepts (delinquent, antisocial, addiction, criminal behaviour, problem behaviour, etc.) that often overlap, we support the opinion of Dolejš (2010) who understands the concept of risk behaviour as superordinate to the above stated concepts. We see the advantage of its application in its width, as it covers all socially inappropriate behaviours, from inconspicuous, little serious forms to the most serious forms.

\section{Theoretical Concepts and Constructs of Risk Behaviour}

The theoretical concepts stated below usually do not "work" with the term "risk behaviour" but with related concepts (deviant, delinquent, criminal, socially pathological behaviour) ${ }^{11}$. Theoretical concepts help not only to understand the causes of serious social problems of the current modern society or the factors influencing the origination of undesirable behaviour, but they can also contribute to eliminate them.

The goal of this part of the article does not consist in covering and presenting the individual theoretical concepts in full scope but offering a survey of theoretical approaches dealing with the phenomenon of risk behaviour. The literature contains different classifications of theories and concepts of social deviations that often complement, combine, overlap, confirm or disprove each other. We can classify them for example by the time of their origination or by identical theoretical bases.

The theoretical concepts ${ }^{12}$ of social deviations can be divided into two basic groups, i.e.: normative concepts and reactive concepts (Hrčka, 2001; Munková, 2001). A normative concept explains social deviation as an aberration from a norm, as violation of norms that are recognized by most members of the given social group and whose observance is required by the group.

The normative approach is opposed by the reactive (sometimes called relativistic) approach to social deviation. According to it, social deviation results from the reaction of the environment to the individual's behaviour. A specific behaviour of an individual or of a group is designated as deviant by the environment, and due to such designation, the individual or the group starts behaving in a deviant manner, in contradiction with the norms. An example of reactive concept of social deviation is for example the theory of labelling.

Social deviations can be also viewed from the biological, psychological and sociological perspective. Although each of the above stated theories focuses on specific features and characteristics of deviant phenomena and behaviours, all of them have something

\footnotetext{
11 We understand risk behaviour as a concept superordinate to these concepts.

12 M. Hrčka (2001), relying upon common or similar theoretical features, divides the theoretical concepts of social deviations into nine basic categories: biological, psychological, structural, subcultural, conflict, control, integration, situational theories and theories of subjective investigation. According to Fischer \& Škoda (2009), deviant behaviour can be divided into three theoretical constructs: biological-psychological theories, social-psychological theories, sociological theories.
} 
in common. They try to find the answer to the question: "Why does deviant behaviour occur, what are the causes of such behaviour?"

Biological theories rank among the oldest theories of social deviations. They focus their attention primarily on the study of criminal behaviour and on the analysis of crime committed, according to them, by a biologically determined individual.

As Komenda (1999) states, such theories assume the existence of defective biological features in deviant individuals, which predetermine the individual's deviant behaviour. And the types of persons predisposed to deviation can be characterized by specific anatomic and physiological features (e.g. body height, skull size, etc.). So deviation can be explained as an aberration from the biological norm individuals with the said abnormality can be considered deviant. Such theories do not attribute much importance to the influence of social environment and to the individual's upbringing; therefore they pay little attention to social phenomena (Hrčka, 2001).

In the $19^{\text {th }}$ century, the biological theories assume importance, primarily thanks to Lombroso's theory of born criminal; based on an extensive anthropological measurement of Italian prisoners, he came to the conclusion that individuals disposing of specific physiological defects caused by inborn hereditary features (the skull shape, in this case) tend to criminal behaviour). The knowledge of such anatomical defects allows detecting a potential perpetrator (Mühlpachr, 2008a). Lombroso also believed that individuals with inborn tendencies to delinquent behaviour could not be changed and reeducated, and therefore they should be isolated for life or executed in order to protect the whole society (Kuchta \& Válková, 2005). Although Lombroso and his followers revised their opinions several times, their approaches were subject to criticism (Hrčka, 2001; Večerka et al. 2004), challenged and some of them disproved. Their greatest contribution can be seen in the fact that when investigating crime, they turned their attention to the delinquent's personality and to the conditions in which the delinquent developed.

They also researched the relation between intelligence and delinquent behaviour. Goddard considered low level of mental capacities one of the main causes of delinquent behaviour (Novotný \& Zapletal, 2008). He relied on the assumption that the lower intelligence a person had, the lower responsibility he/she had for his/her behaviour and due to it, he/she displayed higher tendencies to deviant behaviour. Studies focused on persons placed in prisons or diagnostic, custody and reformatory institutions (e.g. Fischer, 2006a; Koudelková, 1995; Labáth et al. 2001) demonstrated a significant consensus in the finding that a higher number of individuals placed in such institutions displayed a level of mental capacities below average, and that there also were differences in the level of intellectual capacities between delinquent and non-delinquent youth.

In recent years, attention has been paid to search of causes of delinquent behaviour through genetically, enzymatically and hormonally oriented theories. Matoušek and Kroftová $(2003$, ) state that measurements of delinquents often show EEGG abnormalities, increased reactivity of autonomous nervous system and decreased adrenalin values or that they more frequently showed signs of the hyperactivity syndrome, etc. As Lemert (1951, in Hrčka 2001) states, some forms of deviant behaviour can be caused by hereditary 
character of some genes, or by their absence, or by hereditary character of non-specific tendency to deviant behaviour.

Although "some connections of biological equipment and criminality are undeniable" (Havlík, 2007, p. 108), the biological theories cannot be absolutized. The human is a biological organism, determined by biological laws, but the human behaviour is influenced by a number of other factors. A problem of the above stated theories can be seen in the fact that they are based on natural sciences, and therefore cannot explain phenomena with social nature, as they do not consider the influence of social environment. Psychological theories, similarly to biological theories, understand deviation as an aberration, deviants as carriers of abnormality and abnormality as the cause of deviant behaviour.

Psychological theories see the causes of deviant behaviour in human psyche and in mental processes of the human. Although psychologists generally acknowledge that the biological and social environment influences the individual's mental development, they put the main stress on the psychological aspect of shaping of the personality. They deal with the human personality, mental development, motivation, and aggression. When describing the personality, they rely on internal and external characteristics, they also pay attention to disorders in emotional area, insufficient socialization, deprivation, frustration and weakly developed moral values (Mühlpachr, 2008).

The psychological theories of social deviation often rely on Freud's psychoanalysis, stating that mental life is governed by instincts provoking different manners of distraction. Freud sees the basic human instincts in the sexual instinct and in the destruction instinct. If any instinct is suppressed, conflicts may emerge. If a human behaves naturally, without suppressing his instincts, his behaviour may be perceived by the society as nonconforming, aberrating from the norm, i.e. deviant. If, on the contrary, he is conforming with the norms of the society, he is deviant with respect to his own nature (Mühlpachr, 2001). Deviant behaviour "is conditioned by an imbalance between instinctive tendencies to deviation and internalized normative commitments and disorders of psycho-sexual development" (Hrčka, 2001, p. 163).

Deviant behaviour can also be explained with the help of Freud's theory of the development of the superego. The superego is created in the course of the individual's upbringing, and therefore the family and the closest environment play an essential role in its shaping. The cause of the deviant behaviour may consist in an excessively developed superego (strong regulation of behaviour due to extreme awareness of existence of social norms) or, on the contrary, a weak superego (weak, insufficient regulation of behaviour due to weak awareness of existence of social norms). An individual with excessively developed superego often places pointless or impossible demands on himself/herself, based on an excessive awareness of social norms, which may lead to inner tension and dissatisfaction with one's life, resulting in permanent frustration and potential aggressive behaviours. On the contrary, a low emphasis on application and observance of social norms leads to the development of a weak superego. The individual is not able to distinguish exactly what behaviour is correct, he/she does not have sufficient self-control mechanisms, is not able to subdue his/her instinctive tendencies, and therefore has higher predispositions to commit crime (Kota, 2004). 
Psychoanalytical theories understand deviation as the consequence of experiences from early childhood. According to those theories, for example some experiences from childhood, unsolved conflicts and complexes, emotional deprivations or inappropriate upbringing may lead to disorders of psycho-sexual development and to shaping of specific personality features that may result in deviant behaviour (Hrčka, 2001; Jedlička et al., 2004).

Some psychological theories are based on the conviction that social deviation is not hereditary, but can be explained from the perspective of child socialization during which the first attitudes towards social norms and rules are developed. Urbanová (2003) considers the first seven years a very important period in the child's life. If the child lacks mother's love, loving care, intimate mutuality, sense of safety, diverse stimuli developing the child's inner world in the long term, bonds between the mother and the child are not created and the child may start displaying subdeprivation, in extreme cases even psychic deprivation whose consequences are manifested in the individual's mental development and relations to other people all along his/her life. Bowlby (2010) comes to a similar conclusion, believing that a safe emotional bond between the child and the caring person (most frequently mother) has an essential importance for the individual's further development.

The results of studies ${ }^{13}$ dealing with life stories of "unwanted children" show that individuals with symptoms of mental subdeprivations usually had greater health problems, worse school results, higher vulnerability, more frequent relation problems, disciplinary problems, truancy, less friends, more frequent disappointments in love, feeling of insufficient appreciation, of undeserved criticism, and when they were adult, they had problems in sexual and erotic area of life. They often respond to emotional frustration by relief abuse of alcohol, by aggressive behaviour or by self-harming and suicidal activities; they were also found to be involved in criminality more frequently than general population. Similar symptoms could be found also in individuals who had spent their childhood in a children's home. (Jedlička, 2011).

Psychological theories link deviant behaviour also with social learning "in which the individual, in contact with another person or a social group, acquires skills, habits, attitudes needed for social intercourse, 'for life among people', adopts his/her social roles, moral, aesthetic and other norms of the society and experiences shaping of his/her motives and features" (Čáp, 1993, p. 111). Thus we can say that the individual learns and adopts behaviour models that are common in his/her closest social environment. Helus (2004) considers social learning the driving force of the child's socialization.

Imitation is an important mechanism to acquire complex forms of behaviour, attitudes and qualities. The child imitates the behaviour of his/her parents, siblings, other persons from the closest environment, of friends, but also of characters from movies and TV

13 The issues of socialization in childhood, disrupted early relations between the mother and child, deprivation and subdeprivation, their causes and consequences for the individual's further life were researched in more detail for example by: Matějček, Bubleová \& Kovařík, 1997; Fonagy \& Target, 2005; Bowlby, 2010; Jedlička 2011, Langmeier \& Matějček 2012, etc. 
stories. Social learning by imitation usually takes place unconsciously and results from combination of external and internal factors of the imitating individual. Imitation acts as an important factor for example in origination of alcoholism and nicotinism. It was also found that violent behaviour patterns are passed from generation to generation (Kraus \& Hroncová, 2010), i.e. that the children imitate the violent behaviour of their parents when solving conflict situations, they consider it a normal way of conflict solution, and therefore act similarly.

Another form of social learning is reinforcement that is based on the use of rewards and punishments. The parents reward their child for the behaviour that corresponds to their demands and norms. The child reinforces the rewarded behaviour patterns (Čáp, 1993). The same applies to deviant behaviour. If the deviant behaviour was positively accepted and reinforced by the individual's environment, if it was followed by a reward, than the individual is likely to continue such behaviour.

As Hrčka (2001, p. 168) states, human behaviour is not shaped by personality features but primarily by social roles. "Personality features in themselves cannot completely determine the definition of the situation or the individual's behaviour in a specific situation: the thing is that the behaviour is primarily conditioned by social interactions and by the relations and the role executed in the given situation; that's why an individual with specific personality qualities may behave differently in different situations."

Similarly to biological factors, the psychological factors influence significantly the origination and development of the deviant actions, but their effect is not isolated. On the contrary, they must be understood in the context of other effects, primarily of social effects, as neither psychological nor biological theories are able to explain different level of deviation in different cultures and societies.

Additionally to psychological and biological theories, the causes of deviant behaviour can also be explained through sociologically oriented theories. While the biologically and psychologically oriented approaches focus on the individual and on the individual's analysis, dealing with the individual's role and seeing the causes of deviant behaviour in the disturbed personality of the individual, the sociological theories emphasize the influence of the environment, of sociocultural and group factors, concentrating on the influence of the society and attributing crucial importance in origination of social deviations to the society. As Komenda (1999, p. 149) states, sociological theories understand social deviation as a "socially pathological phenomenon that results not from an individual's disorder or disease but from the pathological environment in which the individual must live".

When studying social deviations, sociological concepts rely on two perspectives. On one hand, they ascertain why the deviation emerged, what caused the deviant behaviour; on the other hand, they ascertain what attitude is taken by the society to deviant behaviour actors, i.e. why individuals who applied specific forms of deviant behaviour are stigmatized (Sochůrek, 2009).

Specialized literature (e.g. Fischer \& Škola, 2014; Hrčka, 2001; Keller, 2012; Munková, 2001 , etc.) contains not only different sociologically oriented approaches and constructs 
aimed at explaining the essence of social deviations but also different classification of individual approaches. Some complement and combine each other; others differ from each other more or less or contradict each other.

\section{Conclusion}

Based on the above stated facts, we can state that an individual's delinquent behaviour is influenced by the membership in a specific social group and local environment in which the person moves and which can offer respect, social status, feeling of safety, acknowledgement and meaning of life to the individual. Therefore the membership in the given subculture is important to the individual, even at the cost of potential sanctions. Although the above mentioned theoretical constructs aim at explaining the causes of deviant and delinquent behaviour, we believe that they can be applied to the clarification of the causes and factors leading to the origination of risk behaviour.

We personally see one of the most important factors that may have effect on the behaviour of children and adolescents and that may influence the origination of risk behaviour in the closest social environment in which the child moves, i.e. the family, peers and school. Thus risk behaviour develops primarily in small intimate groups during the socialization process through social learning. The child adopts the behaviour patterns, opinions, and attitudes of the group (in the earliest age from the family; in the adolescence from the peer group); he/she considers "normal" the behaviour presented by such group, and therefore behaves in a similar manner. In our opinion, the concept of differentiated association does not apply only to criminal behaviour but it can be applied also to explain the causes of some risk behaviours, like the use of habit-forming substances, aggressive solution of conflicts, promiscuous way of life, truancy, or addiction to PC games.

Insufficient social control, consisting of formal and informal social control mechanisms at different levels, is involved in the origination and development of risk behaviour as well. Insufficient social control of the state over the sale of alcoholic and tobacco products to persons under 18 years leads to easy accessibility of such products in the market, which can contribute to frequent prevalence of smoking and alcohol drinking by children and adolescents. The research results (e.g.Gecková, 1998; Gecková, M. Pudelský \& J. Van Dijk, 2001, etc.) also show that sufficient parent interest and supervision may act as a protective factor against risk behaviour. Social control mechanisms are present in the school environment too. Social control plays an important role there when influencing risk behaviours like truancy, bullying, aggressive behaviour, consumption of habit-forming substances, or destruction of school property.

We can also often find the theory of labelling in our society. Unfortunately, such approach does not stay out of the school environment either. Some pupils are labelled by their teachers and schoolmates as "problem pupils", "failing students", "repeaters", "swotters", and the environment treats them in compliance with the label, expecting them to behave accordingly, which may lead to increasing frequency and seriousness 
of the individual's risk behaviour, as the individual gives up the effort to show the environment that his/her behaviour does not correspond to the given label, and starts behaving as the environment expects.

Risk behaviour is usually not caused by only one cause, but on the contrary, several different factors are involved in the origination of the risk behaviour. It is therefore adequate to apply the holistic approach when researching the risk behaviour. Hamanová and Hellerová (2000, p. 385) state in this context that "each phenomenon of risk / problem behaviour - and particularly of developed risk / problem behaviour - must be studied in depth and separately and approached specifically and "in a specialized way"; at the same time, a holistic approach to this issue as a whole is evidently needed."

Some risk behaviours often occur together with other risk behaviours; ones condition the origination of the others, which is confirmed also by R. Jessor and S. L. Jessor (1977) who came to the conclusion that a person who displays risk behaviour in one area tends to display risk behaviour also in other areas of life.

Therefore we believe that, within preventive activities, attention should be paid to the whole developing personality of the adolescent and not only to individual risk behaviours. At present, the issue of risk behaviour prevention ranks among hot and intensively discussed topics among teachers, psychologists, health care workers and criminal investigators as wall as among other actors who strive to develop efficient primary prevention in the area of risk behaviour. As Čech (2012) states, the task of primary prevention consists in protecting the individual from negative effects and impacts of risk behaviour. The protection does not consist in isolating the individual, in preventing the individual from contact with risk behaviours, but in influencing the individual educationally and preventively with emphasis on shaping the right attitudes and the necessary knowledge and competences allowing not only to identify risk behaviours but also to resist them efficiently (Čech, 2012).

As it was already stated, risk behaviours become a part of our present life and affect more and more often also the children's population, with children in the role of actors or in the role of victims. To prevent this situation from further developing, it is important to enable the children to identify risk behaviour, socially undesirable behaviour, to become aware of the consequences of specific behaviours, to solve problem situations efficiently and adequately.

In our opinion, a professionally equipped teacher able to implement preventive strategic procedures is an important actor in achieving the goals in the area of risk behaviour prevention. Kubátová (2000) lists the competences a teacher should be equipped with. They include competences in the subject, diagnostic, communicative, intervention, personality-cultivating and consulting areas. Therefore we believe that the issue of risk behaviour, the concept and procedures of efficient prevention should be introduced not only to the existing teachers but also to future teachers, through pregraduate preparation. We also believe that the theoretical constructs and concepts explaining the origination of risk behaviour should be part of pedagogical theory or possibly be included in the curriculum of future teachers. 


\section{References}

Bártlová, S. (1998). Sociální patologie. [Social Pathology]. Brno: Institut dalšího vzdělávání pracovníků ve zdravotnictví. [Institute for Further Education of Healthcare Workers].

Bláha, I. A. (1968). Sociologie. [Sociology]. Prague: Academia.

Bowlby, J. (2010). Vazba. Teorie kvality raných vztahů mezi matkou a dítětem. [Attachment. Theory of Quality of Early Relations between Mother and Child]. Prague: Portál.

Cvečková, M. et al. (2010). Rizikové chování dětí a mladistvých - příciny/následky/ prevence. [Risk Behavior Among Children and Adolescents - Causes/Consequenses/ Prevention]. [online] Accessed 27 September 2012. http://www.urazneninahoda.cz/ke_ stazeni/pro_pedagogy.

Čáp, J. (1993). Psychologie výchovy a vyučování. [Psychology of Education and Teaching]. Prague: Karolinum.

Čáp, J., \& Mareš, J. (2007). Psychologie pro učitele. [Psychology for Teachers]. $2^{\text {nd }}$ ed. Prague: Portál.

Čech, T. (2012). Prevence. [Prevention]. In M. Miovský et al. Výkladový slovník základních pojmů školské prevence rizikového chování. [Expository Dictionary of Basic Concepts of Educational Prevention of Risk Behavior] (pp. 107-112). Prague: Togga.

Dolejš, M. (2010). Efektivní včasná diagnostika rizikového chování u adolescentů. [Effective Early Diagnosis of Adolescent Risk Behavior]. Olomouc: Palacký University.

Erikson, E. H. (2002). Dětství a společnost. [Childhood and Society]. Prague: Argo.

Espozito, C. (1999). Learning in urban blight: School climate and its effect on school performance of urban, minority, low-income children. School Psychology Review, 28(3), 365-377.

Fischer, S. (2006). Sociální patologie. Propedeutika. [Social Pathology. Introduction]. Ústí nad Labem: J. E. Purkyně University.

Fischer, S., \& Škoda, J. (2014). Sociální patologie: závažné sociálně patologické jevy, přičiny, prevence, možnosti řešení. [Social Pathology: Serious Social Pathologies, Causes, Prevention, Possible Solutions]. $2^{\text {nd }}$ extended and updated ed. Prague: Grada.

Fonagy, P., \& Target, M. (2005). Psychoanalytické teorie. Perspektivy z pohledu vývojové psychologie. [Psychoanalytic Theories. Developmental Psychology Perspectives]. Prague: Portál.

Gecková, A. (1998). Rodinné prostredie a vychovne problemové spravanie adolescentov. [Family Environment and Educational Problems with Adolescents Behavior]. Psychológia a patopsychológia dietatáa. [Psychology and Patopsychology of Child], 33(4), 320-329. 
Gecková, A., Pudelský, M., \& Van Dijk, J. (2001). Vplyv percipované sociálnej opory na zdravie a socio-ekonomické rozdiely $\vee$ sociálnej opore adolescentov. [Impact of Perceived Social Support on Health and Socio-economic Differences in Social Support of Adolescents]. Československá psychologie. [Czechoslovak Psychology], 45(1), 7-18.

Geist, B. (1992). Sociologický slovník. [Sociological Dictionary]. Prague: Victoria Publishing.

Giddens, A. (1999). Sociologie. [Sociology]. Prague: Argo.

Gullone, E. \& Moore, S. (2000). Adolescent risk-taking and five-factor model of personality. Journal of Adolescence, 23(4), 393-407.

Hamanová, J., \& Hellerová, P. (2000). Syndrom rizikového chování v dospívání. I. Část. [Risk Behavior Syndrome in Adolescence. Part 1.]. Československá pediatrie [Czechoslovak Pediatrics], 55(6), 380-387.

Hartl, P., \& Hartlová, H. (2000). Psychologický slovník. [Psychological Dictionary]. Prague: Portál.

Havlík, R. (2007). Úvod do sociologie. [Introduction to Sociology]. $5^{\text {th }}$ ed. Prague: Karolinum.

Helus, Z. (2004). Dítě v osobnostním pojetí. Obrat k dítěti jako výzva a úkol pro učitele a rodiče. [Child in Personality Concept. Turnover to Child as a Challenge and Task for Teachers and Parents]. Prague: Portál.

Hrčka, M. (2001). Sociální deviace. [Social Deviance]. Prague: Sociologické nakladatelství [Sociological Publishing House].

Jandourek, J. (2007). Sociologický slovník. [Sociological Dictionary]. 2. ed. Prague: Portál. Jandourek, J. (2012). Slovník sociologických pojmů. [Dictionary of Sociological Concepts]. Prague: Grada.

Jedlička, R. et al. (2004). Děti a mládež v obtížných životních situacích. Nové pohledy na problematiku životních krizí, deviací a úlohu pomáhajících profesí. [Children and Youth in Difficult Life Situations. New Views on the Issue of Life Crises, Deviations and Role of Helping Professions]. Prague: Themis.

Jedlička, R. (2011). Výchovné problémy s žáky z pohledu hlubinné psychologie. [Educational Problems with Pupils from the Perspective of Depth Psychology]. Prague: Portál.

Jelínek, M., Květoň, P., Vobořil, D., Blatná, M., \& Hrdlička, M. (2006). Vrstevnická konformita jako faktor rizikového chování mladistvých: struktura, zdroje, dopady. [Peer Conformity as a Factor of Risk Behavior of Adolescents: Structure, Resources and Impacts]. Československá psychologie. [Czechoslovak Psychology], 50(5), 393-404. 
Jessor, R., \& Jessor S. L. (1977). Problem Behaviour and Psychosocial Development. New York: Acadamis Press.

Jessor, R., Van Den Bos, J., Vanderryn, J., Costa, F. M., \& Turbin, M. S. (1995). Protective factors in adolescent problem behavior: Moderator effects and developmental change. Developmental Psychology, 31(6), 923-933.

Kapr, J. et al. (1997). Sociální deviace, sociologie nemoci a medicíny. [Social Deviance, Sociology of Medicine and IIInes]. $2^{\text {nd }}$ modified edition (reprint). Prague: Sociologické nakladatelství [Sociological Publishing House].

Kauffman, J. M. (2001). Characteristics of Emotional and Behavioral Disorders of Children and Youth. $7^{\text {th }}$ ed. New Jersey: Merrill Prentice Hall.

Keller, J. (2012). Úvod do sociologie. [Introduction to Sociology]. $6^{\text {th }}$ ed. Prague: Sociologické nakladatelství [Sociological Publishing House].

Kohoutek, R. (2000). Základy psychologie osobnosti. [Basics of Personality Psychology]. Brno: CERM.

Komenda, A. (1999). Sociální deviace: historická východiska a základní teoretické prístupy. [Social Deviance: the Historical Background and Basic Theoretical Approaches]. Olomouc: Palacký University.

Kotá, J. (2004). Sociální deviace a společenský rád. [Social Deviance and Social Order]. In R. Jedlička et al. Děti a mládež v obtižných životních situacích. Nové pohledy na problematiku životních krizí, deviací a úlohu pomáhajících profesí. [Children nad Youth in Difficult Life Situations. New views on the Issue of Life Crises, Deviations and Role of Helping Professions] (pp. 63-157). Prague: Themis.

Koudelková, A. (1995). Psychologické otázky delikvence. [Psychological Issues of Delinquency]. Prague: Victoria Publishing.

Kraus, B., \& Hroncová, J. et al. (2010). Sociální patologie. [Social Pathology]. 2nd ed. Hradec Králové: Gaudeamus.

Kubátová, D. (2000). Kompetence učitele a drogová závislost. [Teacher Competence and Drug Addiction]. In: Ostravské dny dětí a dorostu 2000. [Ostrava Days of Youth and Adolescents 2000] (pp. 171-177). Prague: Státní zdravotní ústav [National Institute of Public Health].

Kudrjavcev, V. N. et al. (1988). Sociální deviace. Úvod do obecné teorie. [Social Deviance. Introduction to General Theory]. Prague: Svoboda.

Kuchta, J., \& Válková, H. et al. (2005). Základy kriminologie a trestní politiky. [Basics of Criminology and Criminal Policy]. Prague: C. H. Beck. 
Kwaśniewski, J (1991). Zakres pojęcia i problematyki patologii społecznej. [The Scope of the Concepts and Issues of Social Pathology]. In T. Szymanowski (ed.), Patologia społeczna. Wybrane problem. [Social Pathology. Selected Problems] (pp. 18-28). Warszawa: WSPS.

Labáth, V. et al. (2001). Riziková mládež. Možnosti potenciálních změn. [Youth at Risk. Possibilities of Potential Changes]. Prague: Sociologické nakladatelství [Sociological Publishing House].

Langmeier, J., \& Matějček, J. (2012). Psychická deprivace v dětství. [Psychic Deprivation in Childhood]. $4^{\text {th }}$ amended edition, Prague: Karolinum.

Langer, S. (2001). Problémový žák v době dospívání na základní škole a v nižších třídách gymnázia. [Troubled Teenage Student in Elementary School and Lower Classes of Grammar School]. Hradec Králové: Kotva.

Macek, P. (1999). Adolescence. Psychické a sociální charakteristiky dospívajících. [Adolescence. Psychological and Social Characteristics of Adolescents]. Prague: Portál.

Macek, P. (2003). Adolescence. [Adolescence]. $2^{\text {nd }}$ ed. Prague: Portál.

Marešová, A. (2010). Sociálně patologické jevy. [Socially Pathological Phenomena]. Trestně právní revue [Revue of Criminal Law], 9(2), 52-58.

Mařiková, H., Petrusek, M., \& Vodáková, A. et al. (1996). Velký sociologický slovník I. [Great Sociological Dictionary l]. Prague: Karolinum.

Matějček, Z., Bubleová, V., \& Kovařík, J. (1997). Pozdní následky psychické deprivace a subdeprivace. [Late Effects of Mental Deprivation and Subdeprivation]. Prague: Psychiatrické centrum [Psychiatric Centre].

Matoušek, O. (1996). Práce s rizikovou mládeží projekt LATA a dalši alternativy věznění mládeže. [Working with Youth at Risk: LATA Project and Other Alternatives to Imprisonment of Youth]. Prague: Portál.

Matoušek, O., \& Kroftová, A. (2003). Mládež a delikvence. [Youth and Delinquency]. 2nd updated edition Prague: Portál.

Miovský, M. et al. (2010). Primární prevence rizikového chování ve školství. [Primary Prevention of Risk Behavior in Schools]. Prague: Sdružení SCAN: Centrum adiktologie - Psychiatrická klinika, Klinika adiktologie 1. LF UK a VFN v Praze [SCAN Association: Centre od Adictology - Psychiatric Clinic, Adictology Clinic of the $1^{\text {st }}$ Faculty of Medicine, Charles University and General University Hospital in Prague].

Miovský, M., Adámková, M., \& Barták, M. et al. (2015). Výkladový slovník základních pojmů školské prevence rizikového chování. [Expository Dictionary of Basic Concepst of Risk Behavior School Prevention]. 2nd ed. Prague: Klinika adiktologie 1. LF UK a VFN v Praze 
v Nakladatelství Lidové noviny [Adictology Clinic of the $1^{\text {st }}$ Faculty of Medicine, Charles University and General University Hospital in Prague in Lidové Noviny Publishing].

Mühlpachr, P. (2001). Sociální patologie. [Social Pathology]. Brno: Masarykova univerzita. Mühlpachr, P. (2008). Sociopatologie. [Social Pathology]. Brno: Masaryk University.

Mühlpachr, P. (2008a). Socipatologie pro sociální pracovníky. [Social Pathology for Social Workers]. Brno: MSD.

Munková, G. (2001). Sociální deviace. [Social Deviance]. Prague: Karolinum.

Novotný, J. S., \& Okrajek, P. (2012). Vliv vybraných charakteristik rodinného prostředí na rizikové chování 15tiletých adolescent. [Influence of Selected Characteristics of Family Environment on the Risk Behavior of Adolescents Aged 15]. E-psychologie [E-Psyhology]. [online]. 2012. Accessed 27 December 2012. http: <//e-psycholog.eu/pdf/novotnyokrajek.pdf>.

Novotný, O., \& Zapletal, J. et al. (2008). Kriminologie. [Criminology]. $3^{\text {rd }}$ reworked edition. Prague: ASPI.

Ondrejkovič, P. et al. (2000). Sociálna patológia. [Social Pathology]. Bratislava: VEDA.

Ondrejkovič, P. (2002). Sociálna patológia alebo deviácia? [Social Pathology or Deviance?] In I. Hodovský \& M. Dopita (eds.), Etika a sociální deviace. [Ethics and Social Deviance] (pp. 121-138). Olomouc: Nakladatelství Olomouc [Olomouc Publishing].

Petrusek, M. (2009) Základy sociologie. [Introduction to Sociology]. Prague: Akademie veřejné správy [Public Administration Aacademy].

Piaget, J., \& Inhelderová, B. (2010). Psychologie dítěte. [Child Psychology]. $5^{\text {th }}$ ed. Prague: Portál.

Říčan, P. (2004). Cesta životem. [The Life Journey]. $2^{\text {nd }}$ reworked edition. Prague: Portál.

Říčan, P., \& Krejčírová, D. (2006). Dětská klinická psychologie. [Child Clinical Psychology]. $4^{\text {th }}$ reworked and completed ed. Prague: Grada.

Skopalová, J. (2000). Vybrané kapitoly ze sociálních deviací. [Selected Chapters from Social Deviance]. Olomouc: Palacký University.

Sochưrek, J. (2009). Úvod do sociální patologie. [Introduction to Social Pathology]. Liberec: Technická University in Liberec.

Stankowski, A. (2001). Sociální patologie. [Social Pathology]. Ostrava: Centrum dalšího vzdělávání PdF OU [Center of Further Education, Faculty of Education, University of Ostrava. 
Syřrištová, E. et al. (1972). Normalita osobnosti. [Normality of Personality]. Prague: Avicenum.

Širůček, J., Širǔčková, M., \& Macek, P. (2007). Sociální opora rodičů a vrstevníků a její význam pro rozvoj problémového chování. [Social Support from Parents and Peers and its Importance for the Development of Problem Behavior]. Československá psychologie. [Czechoslovak Psychology], 51(4), 476-488.

Širůčková, M. (2009) Psychosociální souvislosti rizikového chování v adolescenci: role vrstevnických a rodinných vztahů. [Psychosocial Context of Risk Behavior in Adolescence: The Role of Peer and Family Relationships]. Brno. Dissertation. Masaryk University, Faculty of Social Studies.

Širůčková, M. (2012). Rizikové chování. [Risk Behavior]. In M. Miovský et al. Výkladový slovník základních pojmů školské prevence rizikového chování. [Expository Dictionary of Basic Concepts of Risk Behavior School Prevention] (pp. 127-132). Prague: TOGGA.

Urban, L., Dubský, J., \& Bajura, J. (2012). Sociální deviace. [Social Deviance]. $2^{\text {nd }}$ extended edition. Plzeň: Vydavatelství a nakladatelství Aleš Čeněk [Aleš Čeněk Publishing].

Urbanová, M. (2003). Sociální kontrola a právo. [Social Control and Law]. 2nd unchanged edition. Brno: Masaryk University.

Urbanová, M. (2006). Systémy sociální kontroly a právo. [System of Social Control and Law]. Plzeň: Vydavatelství a nakladatelství Aleš Čeněk [Aleš Čeněk Publishing].

Vágnerová, M. (2001). Kognitivní a sociální psychologie žáka základní školy. [Cognitive and Social Psychology of Elementary School Pupil]. Prague: Karolinum.

Vágnerová, M. (2004). Psychopatologie pro pomáhající profese. [Psychopathology for Helping Professions]. $3^{\text {rd }}$ extended and reworked ed. Prague: Portál.

Večerka, K., Holas, J., Štěchová, M., Diblíková, S., \& Neumann, J. (2004). Mladiství pachatelé na prahu tisíciletí. [Juvenile Perpetrators on the Doorstep of New Millennium]. Prague: OKAP.

Vojtová, V. (2004). Kapitoly z etopedie I. Přístupy k poruchám emocí a chování $v$ současnosti. [Chapters from Ethopaedia I. Contemporary Approaches to Disturbances of Emotions and Behavior]. Brno: Masaryk University.

Vojtová, V. (2004a). Edukace žáků s poruchami chování. [Education of Pupils with Behavioral Problems]. In M. Vítková (ed.), Integrativní školní (speciální) pedagogika. Základy, teorie, praxe. [Integrative School (Special) Education. Fundamentals, Theory, Practice] (pp.191-203). $2^{\text {nd }}$ ed. Brno: MSD.

Žlunková, J. (2010). Co do školy nepatří. [What Does Not Belong to School]. Olomouc: Palacký University. 


\section{Authors}

doc. PhDr. Jitka Skopalová, Ph.D.

Faculty of Public Policies, Silesian University in Opava

The Institute of Pedagogical and Psychological Sciences

Bezručovo nám. 885/14, 74601 Opava, The Czech Republic

jitka.skopalova@fvp.slu.cz

Mgr. Petra Hedrichová, Ph.D.

Elementary School

Nedvědova 17, Olomouc, The Czech Republic

petra.hedrichova@zsnedvedova.cz 